\title{
Explaining house price changes in Greece
}

\author{
Dimitrios Gounopoulos ${ }^{a,{ }^{* 1}}$, Andreas G. Merikas ${ }^{b}$, Anna A. Merika ${ }^{c}$ and \\ Anna Triantafyllou ${ }^{\mathrm{c}}$

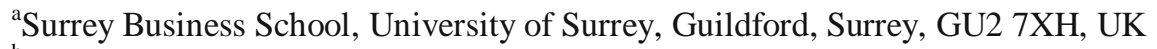 \\ ${ }^{\mathrm{b}}$ Department of Maritime Studies, University of Piraeus, 33-35 Marathonos Street, Voula, \\ 16673, Greece \\ ${ }^{c}$ Department of Economics, The American College of Greece 6 Gravias Street, Aghia Paraskevi, \\ 15342 , Greece
}

This paper develops an equilibrium model for the Greek housing market that incorporates both macroeconomic as well as country-specific variables that affect demand for and supply of houses. In the overall uprising phase of the 23-year period examined (1985Q1-2008Q1), our investigation of short-term fluctuations in real house prices and stock prices confirms the inverse relationship between movements in the housing price index and the stock exchange general index, identifies the direction of causality as running from the financial sector to the real sector, and finds that, following an exogenous shock, reversion to the long-run equilibrium is a rather slow process. Furthermore, we identify a fundamental shift in the behaviour of Greek homeowners, who appear to be moving away from the treatment of housing as consumption good, towards treating house purchases as investment.

Keywords: House price changes, construction costs, housing price index

\footnotetext{
${ }^{1}$ Corresponding author. E-mail: d.gounopoulos@surrey.ac.uk
} 


\section{I.Introduction}

It is well documented in the literature that house prices are closely associated with macroeconomic variables, such as inflation, employment, interest rates, and stock prices. This affect economic cycles (e.g. Higgins and Osler, (1999); Collyns and Senhadji, (2002); Leamer, (2007)) and economic growth, Van Dijk et al. (2009). However, explaining house price movements entails more than mere macroeconomic factors. Household attitudes towards purchases of houses vary along a consumption-investment spectrum. The exact point that households position themselves on this spectrum is critical for the functioning of the housing market: it affects demand, supply and, by implication, the price outcome. For example, if households view house purchases as an act of consumption, they are more likely to hold on to their real asset, rather than, in the event that they wish to make an alternative investment or perceive that they can realize a capital gain, considering entering a secondary market and selling it. In such cases, the supply of houses is doomed to rise at a lower pace than demand, constantly pushing house prices higher. By contrast, if households are willing to consider house purchases as an act of investment, their entrance into a secondary market is more likely, giving supply a greater chance to keep up with rising demand and making house prices more flexible downwards. It, therefore, becomes obvious that meaningful investigation of house price behaviour has to include, but also go well beyond, standard demand and supply analysis.

The importance of the construction sector for the Greek economy, both directly through its contribution to $\mathrm{GDP}^{2}$ and indirectly through the development of backward linkages, together with the traditionally large proportion of housing wealth in Greek households' portfolios give special weight to the exploration of house price dynamics in the Greek housing market. It is worth stating at the outset that the housing market in Greece is one where demand has typically risen faster than supply, house prices have been extremely inflexible downwards, and house purchases have largely related to consumption. Greek households have traditionally treated housing as consumption good and have adopted a

\footnotetext{
${ }^{2}$ Similar in The Netherlands, Van Dijk et al (2001) report that house prices in regions in the first class are characterized by slightly higher average growth rates, and stronger and faster reactions to changes in GDP.
} 
conservative and less risky, the "buy and hold" approach, which has arguably been responsible for steadily rising house prices. Recently, however, particularly with the stock market boom of the late 1990s, there have been signs that household attitudes towards housing may be changing. Although not fully documented, it has not been uncommon for households to sell property in order to invest in the stock market ${ }^{3}$ or, when the circumstances are right, in order to realize a capital gain. A growing secondary market is welcome in the Greek housing market, as it facilitates higher volumes, greater price flexibility, and, in general, smoother functioning of the market.

The purpose of this paper is to identify theoretically sound and practically useful determinants of house prices in the Greek economy. Although macroeconomic variables that affect house prices, as well as the links between house prices, housing wealth and financial wealth have been investigated both for individual economies (including Greece) and for groups of countries, little attention has been paid so far in the relevant literature in extending standard demand and supply analysis to incorporate household attitudes towards purchases of houses and identify their implications for the housing market. The goal of this paper is to fill this gap. We develop an equilibrium model for the Greek housing market that incorporates both macroeconomic as well as country-specific variables that affect demand for and supply of houses. Using data from DSI Statistical Bases from 1985Q1 to 2008Q1, we then employ an empirical framework that allows us to analyze the behaviour of Greek house prices and subsequently quantify the impact and explain the extent to which these determinants impinge upon house price movements. We find a negative relationship between production-excludingconstruction in the real sector and real house prices that lends support to our argument that as house prices in Greece rose over the period examined, the construction sector continued to attract the bulk of investment funds, thus depriving the rest of the economy of vital investment funds. Moreover, in investigating the determinants of stock market performance, we find a positive relation between the stock market general index and the informal sector,

\footnotetext{
${ }^{3}$ In a 2001 article in The Washington Post, the then President of the Athens Stock Exchange, P. Alexakis, points out that some of the Greeks who invested in the stock market for the first time when they saw prices soaring in 1999 did so mortgaging or selling property to raise the funds.
} 
which we take as evidence that the underground economy in general and funds realized via tax evasion in particular eventually find their way to the Greek stock market.

In the overall uprising phase of the 23 -year period examined, our investigation of short-term fluctuations in stock market performance and real house prices supports an inverse relationship between movements in the stock exchange general index and the housing price index, with changes in the stock market index causing opposite changes in house prices and changes in house prices reinforcing this negative relationship in the next period. Measuring the equilibrium adjustment mechanism, we find slow reversion to the long-run equilibrium following an exogenous shock.

Moreover, we find evidence that the more volatile the stock market index the higher the demand for housing and the stronger the positive change in the housing price index appears to be, acting as a hedge mechanism. Together with the inverse relationship between the stock market index and the housing price index, the positive, albeit small in magnitude, correlation of equity market volatility and the change in house prices confirms the substitute nature of stock market investment versus housing market investment, pointing to a fundamental shift in the behaviour of Greek households away from the conservative "buy and hold" attitude, towards treating house purchases as investment, with houses being bought, but also being sold, when alternative investments are available or when capital gains are forthcoming. This shift is of utmost importance for assisting the Greek housing market to eventually operate in a more orthodox manner, with prices going up when demand rises and down when demand falls.

The rest of the paper is organized as follows: A brief survey of related literature is conducted in section 2. Section 3 outlines the importance of construction activities for the Greek economy. Basic characteristics of the Greek construction sector in relation to macroeconomic variables in the 23-year period examined are presented in section 4. Methodology and data and variable selection are outlined in sections 5 and 6 respectively. Section 7 presents empirical findings. Concluding remarks are made in section 8. 


\section{Literature Review}

Of the numerous theoretical attempts to integrate the real estate market, the capital market and construction activity, the works of Fisher (1992) and DiPasquale and Wheaton (1992) stand out. The Fisher-DiPasquale-Wheaton (FDW) model of property market equilibrium was subsequently presented in the seminal textbook in urban economics and real estate markets by DiPasquale and Wheaton (1996).

It distinguishes between the space market and the real estate asset market, linking the spatial demand/supply dynamic to real estate asset values in order to give a more accurate description of the interaction between financial markets and real asset markets. In the FDW model, the cash flows generated by ownership of property are determined in the space market by equating demand for and supply of housing use or space. Demand for space comes from users who need to maintain the same level of space activities. With fixed supply, the price of space, i.e. rent, increases if demand for space increases and falls if demand for space falls. Further, rent is transformed into a market value by discounting at the capitalization rate that reflects the level of real interest rates. Finally, the volume of construction is taken to be a function of the market price of real estate. Construction is forthcoming when market prices are above construction costs. Conversely, construction comes to a halt when market prices are below construction costs.

Existing general equilibrium models with housing include Davis and Heathcote (2005), who explore the implications of a real business cycle model with a construction sector, and Ortalo-Magne and Rady (2006), who analyze an overlapping generations model to study prices and volume in the housing market. However, none of these papers is concerned with financial assets. Cocco (2005), Flavin and Yamashita (2002), and Flavin and Nakagawa (2008) consider portfolio choice with exogenous returns in the presence of housing. However, these models are not set in general equilibrium.

Consumption-based asset pricing models traditionally assume that there is a single consumption good. Eichenbaum et al. (1988) and Jagannathan and Wang (1996) show that 
non separable utility over consumption and leisure does not help explain mean asset returns. Santos and Veronesi (2006) show that the ratio of consumption to labor income forecasts stock returns. However, their pricing kernel is the same as that in the standard model, because utility is separable in consumption and leisure. Their result therefore does not arise from composition risk as we define it. Dunn and Singleton (1986), Eichenbaum and Hansen (1990), and Heaton ((1993), (1995)) consider the consumption Euler equation when utility depends on services from consumer durables. They show that adding consumer durables does not help explain the level of the equity premium

Although it has been hard to distinguish between property purchases as an act of consumption versus property purchases as an act of investment, it is true that real estate typically constitutes the single most important component of the household portfolio, Chau et al. (2007). It is also true that the typical household holds a highly undiversified portfolio, since the majority of households do not participate in the stock market. In Greece, for example, at best one in three households hold stock directly. By contrast, eight in ten households own a home ${ }^{4}$. Even in the US, one in five households hold stock directly, while two in three own a home.

Nevertheless, real estate holdings, even as a consumption decision, do affect investment decisions. A number of studies, (Kapopoulos and Siokis (2005), Ebrahim and Hussain (2010)) confirm that, ceteris paribus, real estate exposure is negatively related to stock and other risky financial asset holdings. Miller et al. (2009) show that after controlling for wealth, income and other household characteristics, the relative share of risky assets is a negative function of the real estate ownership in the US. By contrast, Kapopoulos and Siokis (2005) find that in the case of Greece real estate prices, at least in Athens area, are a function of the General Index of the Athens Stock Exchange. Thus, the inverse relationship between equity and housing investment is well documented, even though the direction of causality is less clear.

\footnotetext{
${ }^{4}$ In 2008, Greek household wealth consisted of real estate (81.8\%), savings (17\%) and stock (1.2\%), while the homeownership rate, at $80.1 \%$, was the second highest in the EU (Hardouvelis, 2009).
} 
In the international arena there are many studies addressing housing prices and bubbles (Kim and Suh (1993), Hui and Yue (2006), Vlamis (2007), Fraser et al. (2008), Fender and Scheicher (2009) and Sarmiento (2009)) but much less researchers address the role of housing price volatility in determining investment decisions. Hossain and Latif (2007) in an effort to identify the determinants of housing price volatility demonstrate that it is affected significantly by gross domestic product (GDP) growth rate, housing price appreciation rate and inflation. Additionally, volatility affects GDP growth rate, housing price appreciation and volatility itself.

As far as the involvement of real estate in the macro-economy is concerned, two main strands of thought can be identified. The first is concerned with spotting and measuring a housing wealth effect on consumption, comparable to the financial wealth effect. This strand examines whether consumer spending responds to changes in housing values, similarly to responding to changes in financial asset values, and tries to assess the relative importance of housing and financial wealth upon consumption. There is wide disagreement among the scholars. Carroll et al., (2006) find that the housing wealth effect is substantially stronger than the financial wealth effect. Case et al. (2005)) find either mixed results or evidence in favour of the financial wealth effect. In certain cases, it has not been possible to find evidence supporting a statistically significant relationship between housing prices and stock prices at all.

A second strand in empirical research investigates housing price dynamics, looking mainly for macro-economic variables that determine changes in house prices (Sutton, (2002); Apergis and Rezitis, (2003), thereby establishing the channels through which housing market sho cks filter though the rest of the economy. Sutton (2002) attributes house price fluctuations in 6 western developed economies to changes in national incomes, interest rates, and stock prices, although in some instances house prices actually increased by more than warranted by these determinants. Inflation tends to be the most important factor in driving house prices in the cross-country study of Piazzeza et al. (2007). Equity prices appear to be a gauge for house 
prices and short-term interest rates to have important implications for house price dynamics in the sample of 13 industrial countries studied by Borio and McGuire (2004). Finally, interest rates, inflation and employment were found important in that order in a case study of Greek housing prices conducted by Apergis and Rezitis (2003).

\section{The Importance of the Construction Sector for the Greek Economy}

Over the past several decades, housing and building construction have played a key role in output growth and employment in the Greek economy. Since the 1960s construction has typically absorbed one-half to one-third of private fixed investment, accounted for 4-10\% of employment, and contributed 5-10\% to Greek GDP. By 2008 the contribution of the construction sector to employment and GDP reached $8.7 \%$ and $10.7 \%$ respectively (Hardouvelis, (2009)).

Strictly speaking, construction is not part of the industrial sector. This is because the output of the construction sector, albeit consumable, does not add to manufacturing value added (MVA), except, perhaps, indirectly via the creation of backward linkages, such as the establishment of manufacturing units that supply construction activities with their output. Therefore, expansion of the construction sector does not necessarily involve industrialization as the engine of growth of the economy. On the contrary, consistent channeling of funds towards the construction sector may deprive other sectors from vital investment funds.

Nevertheless, construction activity may positively affect the economy when associated with increased house ownership, which, in turn, increases household assets, as well as higher house prices, which raise the net worth of households, potentially giving rise to a housing wealth effect. Particularly in the case of Greece, where housing is the single biggest component of household wealth, comprising more than $80 \%$ of total household wealth and the homeownership rate exceeds $80 \%$, developments in the housing market are critical for the growth outlook of the economy. 
Large scale internal migration and limited alternative, especially financial, investment opportunities, coupled by security from inflation and relatively good knowledge of the market, have traditionally made investment in construction particularly attractive in Greece and are largely responsible for the steadily increasing land and housing prices up until the early 1990s. Since then, liberalization of the Greek financial sector, along with fulfillment of the economic criteria for euro-zone membership, has fuelled expectations for higher profitability, replenishing interest in housing investment. Liquidity and credit, vital ingredients for enhanced demand for housing and, therefore, house price rises, have been readily available. As a result, from 1993 to 2007, real house prices soared by $105.3 \%$ or $4.9 \%$ per year on average (Simmiyiannis and Chondroyiannis, (2009)).

Evidently, the contribution of the construction sector to Greek GDP growth has been quite significant. At the same time, the realized increase in house prices has produced substantial wealth for homeowners, fuelling consumption and reinforcing economic growth. Thus, the growth-wealth momentum in the case of the Greek economy has been a closed loop, whereby intense construction activity has brought about increased housing wealth and higher housing wealth has brought about increased consumption, boosting economic growth.

\section{Characteristics of the Greek Construction Sector}

Figure 1 depicts the variability of the real housing price index over the period examined (1985Q1-2008Q1). Evidently, in spite of short-term fluctuations, the real housing price index in Greece has overall been subject to a positive trend. It could, therefore, be argued that steadily growing demand for housing has almost been a permanent characteristic of Greek society.

\section{Insert Figure 1 about here.}

The graph also indicates two clearly distinguishable periods: 1989-1999 and 2000 to the present. During the first period, the real housing price index moved upwards along the lines of the positive trend that had been established since the early 1980s. From the year 2000 
onwards, possibly boosted by the decline in real interest rates, the real housing price index soared, experiencing unprecedented heights.

The late 1990s were marked by positive developments for the Greek economy. As the expectation that Greece would satisfy the criteria for entering the euro-zone became certainty, inflationary expectations subsided and interest rates fell substantially. Figure 2 illustrates that since 1998 the expansion of the economy following the decline in real interest rates was accompanied by lower unemployment.

\section{Insert Figure 2 about here.}

A further characteristic of the Greek construction sector is revealed in figure 3, where total real production excluding construction appears to exhibit an almost unequivocally inverse relationship with the real housing price index. Especially in the post-2000 period, soaring house prices and the resulting higher return expectations appear to have monopolized the interest of investors. This lends support to the argument made earlier, namely that concentration of investment in real estate may have deprived the rest of the economy from vital investment funds.

\section{Insert Figure 3 about here.}

\section{Methodology}

The excellent insight into the distinction between the space market and the real estate asset market given by the FDW model provides the starting point for our analysis of the Greek housing market. We express the model of demand and supply in the real estate market of Greece as follows:

$$
\begin{aligned}
& \mathrm{D}_{\mathrm{t}}=\alpha_{0}+\beta^{\prime} \mathrm{Z}_{1, \mathrm{t}}^{\mathrm{D}}+\gamma^{\prime} \mathrm{Z}_{2, \mathrm{t}}^{\mathrm{D}}+\varepsilon_{\mathrm{t}} \\
& \mathrm{S}_{\mathrm{t}}=\delta_{0}+\lambda^{\prime} \mathrm{Z}_{1, \mathrm{t}}^{\mathrm{s}}+\kappa^{\prime \prime} \mathrm{Z}_{2, \mathrm{t}}^{\mathrm{s}}+\mathrm{u}_{\mathrm{t}}
\end{aligned}
$$

Where, $\mathrm{Z}_{1, \mathrm{t}}^{\mathrm{D}}$ is a vector including the macroeconomic variables affecting demand and $\mathrm{Z}_{2, \mathrm{t}}^{\mathrm{D}}$ is a vector of country specific factors affecting demand. Similarly, $Z_{1, t}^{\mathrm{s}}$ is a vector including the 
macroeconomic variables affecting supply and $Z_{2, t}^{\mathrm{s}}$ is a vector of country specific factors affecting supply.

The demand equation can be expressed as:

$$
D_{t}=\alpha_{0}-\beta_{1} \mathrm{HI}_{\mathrm{t}}-\beta_{2} \mathrm{ASE}_{\mathrm{t}}+\beta_{3} \mathrm{PROD}_{\mathrm{t}}+\beta_{4} \mathrm{~W}_{\mathrm{t}}-\beta_{5} \mathrm{LR}_{\mathrm{t}}-\beta_{6} \mathrm{SR}_{\mathrm{t}}-\gamma_{1} \mathrm{LFPR}_{\mathrm{t}}+\varepsilon_{\mathrm{t}}
$$

In the first place, higher house prices $\left(\mathrm{HI}_{\mathrm{t}}\right)$ reduce demand for houses. Moreover, as it is well documented in the literature, an increase in the stock market index ( $\mathrm{ASE}_{\mathrm{t}}$ ) will reduce demand for home ownership (see, for example, Kapopoulos and Siokis, (2005), Liu and Su (2010), Koetter and Poghosyan (2010)). Increases in industrial production-excludingconstruction $\left(\mathrm{PROD}_{\mathrm{t}}\right)$ are expected to influence positively demand for home ownership, as are increases in wages $\left(\mathrm{W}_{\mathrm{t}}\right)$, the latter taken as a proxy for disposable income. Furthermore, lower long-term interest rates make other assets like bonds less attractive as investments and lead to an increase in demand for home ownership, while an increase in the short-term rate adversely affects mortgages and has a negative impact on the demand for home ownership.

The vector that includes country specific factors should typically include mortgage market characteristics, leverage/indebtedness of households, tax considerations and demographics, as well as some measure of the size of the underground economy, which is estimated to be approximately $40 \%$ of the GDP in Greece. Since we concentrate on macroeconomic factors in this study we assume that all of the influences stated above are included in the error term, except for the underground economy, which we proxy via the Labour Force Participation Rate $\left(\mathrm{LFPR}_{\mathrm{t}}\right)$. We expect LFPR to have a negative impact on demand for home ownership, as decreases in the official labour force participation rate indicate a shift of labour supply towards hidden activities (Tanzi, (1999); Giles, (1999)).

Similarly, the supply equation can be expressed as: 


$$
\mathrm{S}_{\mathrm{t}}=\delta_{0}+\lambda_{1} \mathrm{HI}_{\mathrm{t}}+\lambda_{2} \mathrm{ASE}_{\mathrm{t}}-\lambda_{3} \mathrm{PROD}_{\mathrm{t}}-\lambda_{4} \mathrm{SR}_{\mathrm{t}}-\lambda_{5} \mathrm{CCI}_{\mathrm{t}}-\kappa_{1} \mathrm{LFPR}_{\mathrm{t}}+\mathrm{u}_{\mathrm{t}}
$$

Housing prices $\left(\mathrm{HI}_{\mathrm{t}}\right)$ affect supply positively, as they act as a signal for more profit to be made by investors. Ditto for the stock market index $\left(\mathrm{ASE}_{\mathrm{t}}\right)$, this gives a boost to stock market listed construction firms that could use the equity market as a source of their financing. Furthermore, we expect supply of new houses to be negatively associated with industrial production-excluding-construction $\left(\mathrm{PROD}_{\mathrm{t}}\right)$ and construction costs $\left(\mathrm{CCI}_{\mathrm{t}}\right)$. A negative relationship is also expected of short-run interest rates $\left(\mathrm{SR}_{\mathrm{t}}\right)$, which affect financing and, therefore, costs.

The country specific factor $\kappa^{\prime} Z_{2, t}^{\mathrm{s}}$ includes leverage/indebtedness of developers, tax conditions (e.g. V.A.T.), as well as the underground economy proxy (Labour Force Participation Rate, $\mathrm{LFPR}_{\mathrm{t}}$ ), which accounts for tax evasion practices. It is worth noting that the latter constitute a rather widespread phenomenon in the Greek housing sector. Allegedly, in all housing market transactions only half of the selling price is registered, pointing to significant tax evasion and revenue losses for the government. As in the case of demand, we assume that all of the influences contained in the country specific factor are included in the error term, except for the underground economy proxy $\left(\mathrm{LFPR}_{\mathrm{t}}\right)$, which is expected to have a negative impact on supply.

Next, we establish the equilibrium relationship by equating demand and supply. Solving for housing prices:

$$
\begin{aligned}
& H I_{t}=\frac{\left(\alpha_{0}-\delta_{0}\right)}{\beta_{1}+\lambda_{1}}-\frac{\left(\lambda_{2}+\beta_{2}\right)}{\beta_{1}+\lambda_{1}} A S E_{t}+\frac{\left(\lambda_{3}+\beta_{3}\right)}{\beta_{1}+\lambda_{1}} P R O D_{t}+\frac{\beta_{4}}{\beta_{1}+\lambda_{1}} W_{t}+ \\
& +\frac{\left(\lambda_{4}+\beta_{6}\right)}{\beta_{1}+\lambda_{1}} S R_{t}+\frac{\lambda_{5}}{\beta_{1}+\lambda_{1}} C C I_{t}-\frac{\beta_{5}}{\beta_{1}+\lambda_{1}} L R_{t}+\frac{\left(\kappa_{1}-\gamma_{1}\right)}{\beta_{1}+\lambda_{1}} L F P R_{t}+v_{t}
\end{aligned}
$$

In the context of this theoretical model, we expect the following a priori conditions to hold:

$$
\left.\frac{\partial H I}{\partial C C I}\right\rangle 0, \frac{\partial H I}{\partial L R}\left\langle 0, \frac{\partial H I}{\partial P R O D}\left\langle 0, \frac{\partial H I}{\partial L F P R}\left\langle 0, \frac{\partial H I}{\partial W}\right\rangle 0, \frac{\partial H I}{\partial A S E}\left\langle 0, \frac{\partial H I}{\partial S R}\right\rangle 0,\right.\right.
$$


In the ensuing two sections, we investigate the data, performing a unit root test and then the Johansen cointegration test. We use an error correction model in order to capture the long-run equilibrium together with the short-run dynamics.

\section{Data Set - Variable Selection}

Quarterly time-series data was collected for 1985Q1 to 2008Q1. Overall, the period under examination coincides with a period of substantial growth realized by the Greek economy. With construction traditionally constituting a major driver of economic growth in Greece, an in-depth investigation of the interrelationships between the real and the financial sectors during the uprising part of a long-run business cycle gives useful insight into both the past and the future.

We collected data on the housing price index, the unemployment rate, the long-run interest rate, the short-run interest rate, the Athens Stock Exchange General Index, and the total production index excluding construction. CPI data were used to transform nominal variables into real. Furthermore, we collected data on the construction cost index, the labor force participation rate and the wage rate. All data were gathered from the same database, DSI, except for the Athens Stock Exchange General Index, which was derived from the Athens Stock Exchange.

\section{Insert Table 1 about here}

The following variables were chosen for our model:

HI: The Real Housing Price Index. It serves as a proxy for the decision variable.

ASE: The General Athens Stock Exchange Index. It serves as a proxy for activity in the financial sector of the economy.

UN: The official Unemployment Rate. It reflects the specific phase of the business cycle of the economy. 
LR: The real Long-Run Interest Rate. It indicates periods of expansion or contraction in the economy.

SR: The real Short-Run interest rate.

W: The real wage rate, as a proxy for income effects.

LFPR: The Labor Force Participation Rate, as a proxy for the underground economy.

CCI: The Construction Cost Index, as a proxy for the supply side in the industry.

CPI: The Consumer Price Index. It serves as a proxy for the average general price level.

PROD: The Production Index in real terms of all other sectors excluding construction. It is used as a proxy for the output growth in the economy apart from construction.

VARE: It is a measure of the volatility of the Athens Stock Exchange Index, ASE, obtained by estimating AR(2), the autoregressive model of order 2 of the ASE, saving the residuals and constructing their variance.

We used the E-Views statistical package for the data set formation and model estimation. Table I presents the descriptive statistics for each variable used.

We observe that all variables with the exception of wages (W) are normally distributed, which facilitates our decision as to the choice of the estimation method. Further, all data series were tested for stationarity using the ADF unit root test (table II). All variables are found to be integrated of order one, I(1), except for the CPI which is integrated of order two, I(2).

\section{Insert Table 2 about here}

\section{Empirical Findings}

The Johansen cointegration test is run among all the variables cited above, except for: a) CPI, which is integrated of order two, I(2) and b) UN, which is highly collinear with PROD. On the basis of the results presented in table III, the test for the null hypothesis $\mathrm{H}_{0}: \mathrm{r} \leq$ $\mathrm{R}$ against $\mathrm{H}_{\mathrm{A}}: \mathrm{r}>\mathrm{R}$ is rejected not only at the $5 \%$ level but also at the $1 \%$ level. This implies that there are two cointegrated vectors in the system, while the potential number is six (one 
less than the variables we included in the determination of our model). We choose the two cointegrating vectors that are consistent with the a priori conditions posed above.

The first cointegrating vector indicates that one long term equilibrium between the Housing Price Index and the variables under consideration is the one stated below. Similarly, long term equilibrium exists between the Athens Stock Exchange General Index and the variables under consideration.

$$
\begin{aligned}
& \mathrm{HI}=0.6123+0.839 \mathrm{CCI}-0.0047 \mathrm{LR}-0.5265 \mathrm{PROD}-0.319 \mathrm{LFPR}+0.077 \mathrm{~W} \\
& \begin{array}{llllll}
(0.1613) & (0.0889) & (0.0015) & (0.0834) & (0.3554) & (0.0518)
\end{array} \\
& \text { (Standard errors in parentheses) } \\
& \mathrm{ASE}=-11.906-2.4549 \mathrm{CCI}-0.0372 \mathrm{LR}+4.9474 \mathrm{PROD}+20.7496 \mathrm{LFPR}+1.9255 \mathrm{~W} \\
& \begin{array}{lllll}
(1.060) & (0.5845) & (0.0102) & (0.5486) & (2.3366)
\end{array} \\
& \text { (Standard errors in parentheses) }
\end{aligned}
$$

The second stage of cointegration analysis involves building an Error Correction Model (ECM). If two or more series are cointegrated, there exist common factors that affect them and their permanent or secular trends and, therefore, the series will eventually adjust to equilibrium. This implies that even if in the short-run the covariance between the dependent and the explanatory variables indicates that they drift apart, in the long-run the series will adjust to equilibrium. This is because some weighted difference of the two series has a finite constant mean and variance.

We proceed to examine the short-run dynamics of the system through an error correction model and explain how the error correction mechanism works. We subsequently identify a causal flow in the cointegrated system, i.e. turning points in one series that precede turning points in the other, indicating a lead-lag relationship between our two variables HI and ASE.

The model is structured in such a way so that short-run deviations from the long run equilibrium will be corrected. The two cointegrated relationships we established in the procedure so far are estimated by OLS and the following ECM is identified: 


\section{Insert Table 3 about here.}

Removing the variables that are not significant at $10 \%$ level results in:

\section{Insert Table 4 about here.}

All the estimated values of the coefficients of the error correction terms in the equations above have the correct sign for an error correction mechanism. The coefficient of the HI equation must be negative and the coefficient of the ASE equation must be positive in order for the deviations from the long-run equilibrium to be corrected. To verify this, we may assume that the error correction term is large and positive. In this case, HI will decrease because its coefficient is negative and ASE will increase because its coefficient is positive. Both result in reduction of the error correction term and, therefore, error correction.

The magnitudes of the coefficients determine the speed of adjustment following an exogenous shock to the long-run equilibrium. In our case, these coefficients are rather small ( $0.2 \%$ and $9 \%$ adjustment in each quarter respectively) indicating that the adjustment is not quick and the reversion to long-run equilibrium, as determined by the error correction term, will be rather slow.

The test for cointegration developed by Engle and Yoo (1987) is based on the significance of the coefficients of the error term. We observe that the disequilibrium term in the second equation is highly significant. Thus, the Engle and Yoo procedure indicates that the two variables are indeed cointegrated.

We proceed with examining the t-ratios in the estimated model. The t-ratio on the lagged disequilibrium term in the ASE equation is significant, revealing that the error correction mechanism is operating primarily through the adjustment of the stock exchange, rather than the adjustment of housing prices (the lagged disequilibrium term has an insignificant effect in the housing index equation). 
We observe that the coefficient on the error correction term is positive and significant in the ASE equation. This implies that when the error correction term is above its equilibrium value, ASE increases and the error correction term falls, moving closer to equilibrium. Similarly, when the error correction term is below equilibrium, ASE adjusts downwards and the error correction term increases towards its equilibrium value. We, therefore, conclude that movements in equity prices tend to precede movements in housing prices. This is in consent with the generic observation that the financial sector in general and the stock market in particular turn down prior to recessions and rise before recovery of the real sector (Siegel, 2002).

In the HI equation, after removing the insignificant variables, we observe that the sign and significance of the remaining variables are according to our priori theoretical expectations. First, the construction cost index (CCI) is positively related to and has a substantial impact upon the housing price index (HI). Second, wages (W) have a significant impact in the right direction on the housing price index, $(\mathrm{HI})$. Moreover, the proxy for the volatility of ASE (VARE) is positively related to the housing price index, which is expected to be so since periods of high volatility tend to go hand in hand with declines in stock market indices. In such circumstances, housing is treated as a safe heaven by investors and this is captured in the above relationship. Finally, production-excluding-construction (PROD) is found to be negatively related and to exert a significant influence on house prices as originally assumed. This is one of the salient features of the Greek economy over the years, with the rate of absorption of investment funds in construction tending to be inversely related to the rate of absorption of investment funds by the rest of the economy.

Proceeding to the second equation of our model, we note that the labour force participation rate (LFPR), which we used as a proxy for the underground economy, is found to be significant and negatively related with the change in ASE. This may be taken as evidence that the underground economy (and especially tax evaded funds) find their way to the stock exchange. Furthermore, we observe confirmation of the inverse relationship 
between stock exchange volatility (VARE) and changes in ASE. Also, the housing price lagged by one period is inversely related to ASE, implying that it Granger causes changes in ASE and verifying the substitute nature of these two different types of investment.

Figure 4 uses the estimated model to track the effect of a shock on both ASE and HI over time. The horizontal axis refers to quarters, since the data used in this model is quarterly. Assuming no further shocks but only the initial to both variables, the figure shows the expected path of both variables over the next 10 quarters. Perhaps more importantly, substitutability between stock market investment and housing market investment, albeit small in magnitude, points to a fundamental shift in the behaviour of Greek households away from the old-fashioned "buy and hold" attitude, which relates to treating housing as pure consumption and has been largely responsible for steadily rising house prices independently of the phase of the business cycle the economy is at, towards treating house purchases as investment. In Greece, demand for housing has consistently risen faster than supply, leading to constantly rising prices. There has been a big primary market and very little of a secondary market. Even when the stock market was at its peak and households sold property in order to take advantage of the rise, the rate of growth of house prices fell only sluggishly from $14.4 \%$ in 1998 to 8.9\% in 1999 (Bank of Greece, (2008)). The apparent shift in household behaviour observed since the mid-1990s is a step in the right direction, as it evidently assists house prices to follow the cyclical fluctuations of demand and, by implication, the entire Greek housing market to operate in a more orthodox manner.

\section{Insert Figure 4 about here.}

\section{Concluding Remarks}

The purpose of this paper has been to identify theoretically sound and practically useful determinants of house prices in the Greek economy. In the context of an FDW model, we develop an equilibrium model for the Greek housing market that incorporates both macroeconomic, as well as country-specific, variables that affect demand for and supply of 
houses. The unique element of our paper is that we use an empirical framework that allows us to analyze the behaviour of house prices in Greece during 1985Q1-2008Q1.

We find that construction costs and wages positively affect house prices, while longterm interest rates, the presence of the informal sector, and production excluding construction affect house prices in a negative manner. The apparent negative relationship between production in the real sector less construction and real house prices lends support to our argument that as house prices in Greece rose over the period examined, the construction sector continued to attract the bulk of investment funds, thus depriving the rest of the economy of vital investment funds.

Furthermore, we find that construction costs and long-term interest rates negatively affect stock market performance. By contrast, equity prices are positively affected by wages, production excluding construction and the presence of the informal sector. The latter constitutes evidence that the underground economy in general and funds realized via tax evasion in particular eventually find their way to the Greek stock market.

In the overall uprising phase of the 23-year period examined, our investigation of short-term fluctuations in stock market performance and real house prices leads to two major conclusions. First, the inverse relationship between movements in the stock exchange general index and the housing price index is confirmed. The direction of causality is identified as running from the financial sector to the real sector. When equity prices fall, households resort to the housing market, pushing house prices higher. Moreover, positive developments in the housing market in a given quarter exert a negative influence upon stock prices in the ensuing quarter, reinforcing the observed negative relationship between the stock market index and the housing price index. Additionally, when measuring the equilibrium adjustment mechanism, we find that, following an exogenous shock, reversion to the long-run equilibrium is a rather slow process.

Second, we find evidence that the more volatile the stock market index the higher the demand for housing and the stronger the positive change in the housing price index appears to 
be. Together with the inverse relationship between the stock market index and the housing price index, the positive correlation of equity market volatility and the change in house prices confirms the substitute nature of stock market investment versus housing market investment. More importantly, the confirmed substitutability between stock market investment and housing market investment, albeit small in magnitude, points to a fundamental shift in the behaviour of Greek households away from the old-fashioned "buy and hold" attitude towards treating house purchases as investment. The apparent shift in household behaviour observed since the mid-1990s is critical in assisting house prices to follow the cyclical fluctuations of demand and, by implication, in promoting smoother operation of the entire Greek housing market.

\section{References}

Apergis, N. and Rezitis, A. (2003) Housing prices and macroeconomic factors in Greece: Prospects within the EMU, Applied Economic Letters, 10, 799-804.

Bank of Greece, 2008, Annual Report of the Governor, (Athens).

Borio, C. and McGuire, P. (2004) Twin peaks in equity and housing prices?, BIS Quarterly Review 79-93.

Carroll, C.D., Otsuka, M. and Slacalek, J. (2006) How large Is the housing wealth effect? A new approach, NBER Working Paper No. 12746.

Case, K. E., J. M. Quigley, and R. J. Shiller, (2005) Comparing wealth effects: The stock market vs. the housing market, Advances in Macroeconomics, 5, 1-35. 
Chau, K. W., Wong, S. K. and Yiu, C. Y. (2007) Housing Quality in the Forward Contracts Market, Journal of Real Estate Finance and Economics, 34, 313-325.

Cocco, J. (2005) Portfolio choice in the presence of housing, Review of Financial Studies, 18, $535-567$.

Collyns, C. and Senhadji, A. (2002) Lending booms, real estate bubbles and the Asian crisis, IMF Working Paper 20.

Davis, M. and Heathcote, J. (2005) Housing and the business cycle, International Economic Review, 46, 751-784.

DiPasquale, D. and Wheaton, W. (1992) The markets for real estate assets and space: A conceptual framework, Real Estate Economics, 20, 181-197.

DiPasquale, D. and Wheaton, W. (1996) Urban Economics and Real Estate Markets (Prentice Hall).

Dunn, K. and Singleton, K. (1986) Modeling the term structure of interest rates under nonseparable utility and durability of goods, Journal of Financial Economics, 17, 27-55.

Ebrahim, M.S. and Hussain, S. (2010) Financial development and asset valuation: The special case of real estate, Journal of Banking and Finance, 34, 150-162.

Eichenbaum, M. and Hansen, L.P. (1990) Estimating models with intertemporal substitution using aggregate time series data, Journal of Business and Economic Statistics, 8, 5369.

Eichenbaum, M. Hansen, L.P. and Singleton, K. (1988) A time series analysis of representative agent models of consumption and leisure choice under uncertainty, Quarterly Journal of Economics, 103, 51-78.

Engle, R. F. and B. Yoo, (1987) Forecasting and testing in cointegrated systems, Journal of Econometrics, 35, 143-159.

Fender, I. and M. Scheicher, (2009) The pricing of subprime mortgage risk in good times and bad: evidence from the ABX.HE indices, Applied Financial Economics, 19, 1925 1945. 
Fisher, J. (1992), Integrating research on markets for space and capital, Real Estate Economics, 20, 161-180.

Flavin, M. and S. Nakagawa, (2008) A model of housing in the presence of adjustment costs: a structural interpretation of habit persistence, American Economic Review, 98, 474495.

Flavin, M. and T. Yamashita, (2002) Owner-occupied housing and the composition of the household portfolio, American Economic Review, 92, 345-362.

Fraser, P., M. Hoesli, and L. McAlevey, (2008) House prices and bubbles in New Zealand, Journal of Real Estate Finance and Economics, 37, 71-91.

Giles, D.E.A. (1999) Measuring the hidden economy: Implications for econometric modelling, Economic Journal, 190, 370-380.

Hardouvelis, G. (2009) The Importance of the housing market for the Greek Economy, The Real Estate Market: Recent Developments and Prospects (Bank of Greece, Athens).

Heaton, J. (1993) The interaction between time-non separable preferences and time aggregation, Econometrica, 61, 353-385.

Heaton, J. (1995) An empirical investigation of asset pricing with temporally dependent preference specifications, Econometrica, 63, 681-717.

Higgins, M. and Osler, C. (1999) Asset market hangovers and economic growth: The OECD during 1984-1993, Oxford Review of Economic Policy, 13, 110-134.

Hossain, B. and Latif, E. (2007) Determinants of housing price volatility in Canada: a dynamic analysis, Applied Economics, 41, 3521 - 3531.

Hui, E.C.M, and Yue, S. (2006) Housing Price Bubbles in Hong Kong, Beijing and Shanghai: A Comparative Study, Journal of Real Estate Finance and Economics, 33, 299-327.

Jagannathan, R. and Wang, Z. (1996) The conditional CAPM and the cross-section of expected returns, Journal of Finance, 51, 3-53.

Kapopoulos, P. and Siokis, F. (2005) Stock and real estate prices in Greece: Wealth versus 'Credit-price’ effect, Applied Economic Letters, 12, 125-128. 
Kim, K. H. and Suh, S.H. (1993) Speculation and price bubbles in the Korean and Japanese real estate markets, Journal of Real Estate Finance and Economics, 6, 73-87.

Koetter, M. and Poghosyan, T. (2010) Real estate prices and bank stability, Journal of Banking \& Finance, 34, 1129-1138.

Leamer, E. (2007) Housing is the business cycle, NBER Working Paper.

Liu, Y.S. and Su, C.W. (2010) The relationship between the real estate and stock markets of China: evidence from a nonlinear model, Applied Financial Economics, forthcoming.

Miller, N., Peng, L. and Sklarz, M. (2009) House Prices and Economic Growth, Journal of Real Estate and Finance and Economics, forthcoming.

Ortalo-Magne, F., and Rady, S. (2006) Housing market dynamics: on the contribution of income shocks and credit constraints, Review of Economic Studies, 73, 1078-1098.

Piazzesi, M., Schneider, M. and Tuzel, S. (2007) Housing, consumption and asset pricing, Journal of Financial Economics 83, 531-569.

Santos, T. and Veronesi, P. (2006) Labor income and asset returns, Review of Financial Studies, 19, 1-44.

Sarmiento, C. (2009) Regime changes in sub-prime margins under the US housing bubble, Applied Financial Economics, 19, 175-182.

Simiyiannis, G., and Hondroyiannis, G. (2009) Real estate prices: The recent Greek experience, in Bank of Greece, ed.: The Real Estate Market: Recent Developments and Prospects (Athens).

Sutton, G.D., 2002, Explaining changes in house prices, BIS Quarterly Review, 46-55.

Tanzi, V., (1999) Uses and Abuses of estimates of the Underground Economy, Economic Journal, 109, 338-347.

Van Dijk, B., Franses, P.H., Paap, R. and Van Dijk, D. (2009) Modelling regional house prices, Applied Economics, 44, 225-246.

Vlamis, P., (2007) Default Risk of the UK real estate companies: Is there a macro-economy Effect, Journal of Economic Asymmetries, 4, 99-117. 
Acknowledgments

We gratefully acknowledge Chinmoy Ghosh, Osama Khan, Dean Paxson, Prodromos Vlamis, Frank Skinner, Lai Van Son for stimulating comments. We would like to thank meeting participants of the European Financial Management Association (EFMA 2009) in Milan for helpful comments on earlier versions of this paper 
Table 1. Descriptive Statistics

\begin{tabular}{|c|c|c|c|c|c|c|c|c|c|c|}
\hline & ASE & CCI & CPI & $\mathrm{HI}$ & LFPR & LR & PROD & SR & UN & $\mathrm{W}$ \\
\hline Mean & 0.4353 & 0.6810 & 0.6682 & 0.6476 & 0.3741 & 12.1895 & 0.9002 & 12.40398 & 8.7718 & 1.0542 \\
\hline Median & 0.3100 & 0.7280 & 0.7441 & 0.7120 & 0.3800 & 12.1500 & 0.8565 & 11.12167 & 8.7000 & 1.1111 \\
\hline Maximum & 1.3040 & 1.1842 & 1.1144 & 1.2178 & 0.4200 & 24.0000 & 1.0370 & 24.00000 & 12.100 & 2.2000 \\
\hline Minimum & 0.0100 & 0.1696 & 0.1465 & 0.1477 & 0.3100 & 2.06000 & 0.7870 & 3.410000 & 6.3000 & 0.2196 \\
\hline Std. Dev. & 0.3565 & 0.2955 & 0.3009 & 0.3044 & 0.0336 & 7.73817 & 0.0873 & 7.315098 & 1.6756 & 0.5365 \\
\hline Skewness & 0.7227 & -0.2023 & -0.3106 & -0.0812 & -0.4659 & -0.01382 & 0.2362 & 0.130614 & 0.0971 & 0.1782 \\
\hline Kurtosis & 2.4011 & 1.7991 & 1.7414 & 1.9337 & 1.8204 & 1.38573 & 1.3134 & 1.325351 & 1.7578 & 2.1995 \\
\hline Jarque-Bera & 9.7925 & 6.4240 & 7.8797 & 4.6526 & 9.0394 & 10.4264 & 12.271 & 11.49076 & 6.3227 & 3.0710 \\
\hline Probability & 0.0074 & 0.0402 & 0.0194 & 0.0976 & 0.0108 & 0.00544 & 0.0021 & 0.003198 & 0.0423 & 0.2153 \\
\hline Sum & 41.798 & 65.377 & 64.155 & 62.173 & 35.920 & 1170.20 & 86.428 & 1190.782 & 842.10 & 101.208 \\
\hline Sum Sq. Dev. & 12.075 & 8.3001 & 8.6016 & 8.8076 & 0.1075 & 5688.54 & 0.7246 & 5083.512 & 266.73 & 27.3511 \\
\hline Observations & 96 & 96 & 96 & 96 & 96 & 96 & 96 & 96 & 96 & 96 \\
\hline
\end{tabular}

Notes: HI: The Real Housing Price Index. It serves as a proxy for the decision variable, ASE: The General Athens Stock Exchange Index. It serves as a proxy for activity in the financial sector of the economy, UN: The official Unemployment Rate. It reflects the specific phase of the business cycle of the economy, LR: The real Long-Run Interest Rate. It indicates periods of expansion or contraction in the economy, SR: The real Short-Run interest rate, W: The real wage rate, as a proxy for income effects, LFPR: The Labor Force Participation Rate, as a proxy for the underground economy, CCI: The Construction Cost Index, as a proxy for the supply side in the industry, CPI: The Consumer Price Index. It serves as a proxy for the average general price level, PROD: The Production Index in real terms of all other sectors excluding construction. It is used as a proxy for the output growth in the economy apart from construction, VARE: It is a measure of the volatility of the Athens Stock Exchange Index, ASE, obtained by estimating $\mathrm{AR}(2)$, the autoregressive model of order 2 of the ASE, saving the residuals and constructing their variance. 
Table 2. ADF Test (with Intercept)

\begin{tabular}{lllll}
\hline & t-statistic & & t-statistic & t-statistic \\
\hline ASE & -1.98 & $\Delta$ ASE & -5.35 & \\
CCI & -1.69 & $\Delta$ CCI & -3.29 & $\Delta(\Delta \mathrm{CPI})$ \\
CPI & -1.52 & $\Delta$ CPI & -1.55 & -19.87 \\
HI & 0.18 & $\Delta$ HI & -8.56 & \\
LFPR & -0.016 & $\Delta$ LFPR & -15.46 & \\
LR & -0.33 & $\Delta$ LR & -7.83 & \\
PROD & -0.96 & $\Delta$ PROD & -11.73 & \\
SR & -0.57 & $\Delta$ SR & -6.58 & \\
UN & -1.02 & $\Delta \mathrm{UN}$ & -8.34 & \\
W & 2.5 & $\Delta \mathrm{W}$ & -7.76 &
\end{tabular}

Note: The MacKinnon critical value for rejection of hypothesis of a unit root at $1 \%$ is -3.48 , at $5 \%$ it is -2.89 , and at $10 \%$ it is -2.58 . 
Table 3. Estimation of the Decision Making Model

\begin{tabular}{|c|c|c|}
\hline Variable & $\begin{array}{l}\text { Coefficients with } \Delta(\mathrm{HI}) \text { as the } \\
\text { Dependent Variable }\end{array}$ & $\begin{array}{l}\text { Coefficients with } \Delta(\mathrm{ASE}) \text { as the } \\
\text { Dependent Variable }\end{array}$ \\
\hline $\mathbf{C}$ & $\begin{array}{c}-0.0056 \\
(-0.8840)\end{array}$ & $\begin{array}{c}\mathbf{0 . 0 0 8 4} \\
(\mathbf{0 . 6 6 9 1})\end{array}$ \\
\hline$\Delta(\operatorname{ASE}(-1))$ & $\begin{array}{c}0.0172 \\
(\mathbf{0 . 8 6 3 6})\end{array}$ & $\begin{array}{c}0.3392 \\
(\mathbf{3 . 2 2 2 8})\end{array}$ \\
\hline$\Delta(\operatorname{ASE}(-2))$ & $\begin{array}{c}-0.0045 \\
(-0.2181)\end{array}$ & $\begin{array}{c}\mathbf{0 . 2 7 8 9} \\
(\mathbf{2 . 5 4 2 7})\end{array}$ \\
\hline$\Delta(H I(-1))$ & $\begin{array}{c}-0.0045 \\
(-0.0423)\end{array}$ & $\begin{array}{l}-1.6729 \\
(-2.9299)\end{array}$ \\
\hline$\Delta(\mathbf{H I}(-2))$ & $\begin{array}{c}-0.0637 \\
(-0.5907)\end{array}$ & $\begin{array}{c}-0.5886 \\
(-1.0345)\end{array}$ \\
\hline$\Delta(\mathrm{CCI})$ & $\begin{array}{c}0.2539 \\
(3.7596)\end{array}$ & $\begin{array}{c}1.2264 \\
(3.4432)\end{array}$ \\
\hline$\Delta(\mathbf{L R})$ & $\begin{array}{c}0.0009 \\
(\mathbf{0 . 5 6 9 0})\end{array}$ & $\begin{array}{c}0.0056 \\
(0.6652)\end{array}$ \\
\hline$\Delta($ PROD $)$ & $\begin{array}{c}-0.1069 \\
(-1.3564)\end{array}$ & $\begin{array}{c}-0.7618 \\
(-1.8334)\end{array}$ \\
\hline$\Delta($ LFPR $)$ & $\begin{array}{c}-0.1324 \\
(-0.8512)\end{array}$ & $\begin{array}{c}-1.3867 \\
(-1.6904)\end{array}$ \\
\hline$\Delta(\mathbf{W})$ & $\begin{array}{c}0.1256 \\
(2.0816)\end{array}$ & $\begin{array}{c}0.3152 \\
(0.9906)\end{array}$ \\
\hline ECT & $\begin{array}{c}-0.0056 \\
(-0.8840)\end{array}$ & $\begin{array}{c}0.0965 \\
(2.8607)\end{array}$ \\
\hline $\begin{array}{c}\text { Adj. } \mathbf{R}^{2} \\
\text { F-Statistic }\end{array}$ & $\begin{array}{l}0.25 \\
2.00\end{array}$ & $\begin{array}{l}0.42 \\
2.07\end{array}$ \\
\hline
\end{tabular}

*(t-statistic in brackets)

Removing the variables that are not significant at $10 \%$ level results in: 
Table 4. Final Version of the Estimated Model

\begin{tabular}{|c|c|c|}
\hline Variable & $\begin{array}{l}\text { Coefficients with } \Delta(\mathrm{HI}) \text { as the } \\
\text { Dependent Variable }\end{array}$ & $\begin{array}{l}\text { Coefficients with } \Delta \text { (ASE) as the } \\
\text { Dependent Variable }\end{array}$ \\
\hline C & $\begin{array}{c}\mathbf{0 . 0 0 6 4} \\
(3.4773)\end{array}$ & $\begin{array}{c}-0.0036 \\
(-0.3181)\end{array}$ \\
\hline$\Delta(\operatorname{ASE}(-1))$ & - & $\begin{array}{c}0.5327 \\
(4.7171)\end{array}$ \\
\hline$\Delta(\mathbf{H I}(-1))$ & - & $\begin{array}{l}-1.4525 \\
(-2.4862)\end{array}$ \\
\hline$\Delta(\mathbf{C C I})$ & $\begin{array}{c}0.2333 \\
(3.8995)\end{array}$ & $\begin{array}{c}1.0677 \\
(3.1494)\end{array}$ \\
\hline$\Delta$ (PROD) & $\begin{array}{c}-0.0084 \\
(-1.7396)\end{array}$ & - \\
\hline$\Delta($ PROD(-1)) & - & $\begin{array}{c}\mathbf{0 . 9 3 4 6} \\
(\mathbf{2 . 2 3 6 4 )}\end{array}$ \\
\hline$\Delta(\mathbf{L F P R})$ & - & $\begin{array}{c}-1.4281 \\
(-1.7220)\end{array}$ \\
\hline$\Delta(W)$ & $\begin{array}{c}0.1222 \\
(2.1186)\end{array}$ & $\begin{array}{c}\mathbf{0 . 3 8 5 2} \\
(\mathbf{1 . 6 3 2 4})\end{array}$ \\
\hline VARE(-1) & $\begin{array}{c}0.0090 \\
(1.9437)\end{array}$ & $\begin{array}{c}-0.0678 \\
(-1.7537)\end{array}$ \\
\hline ECT & $\begin{array}{c}-0.0024 \\
(-0.4029)\end{array}$ & $\begin{array}{l}0.0931 \\
(2.800)\end{array}$ \\
\hline Adj. $\mathbf{R}^{2}$ & 0.26 & 0.41 \\
\hline F-Statistic & 3.32 & 4.11 \\
\hline $\begin{array}{l}\text { Adj. Q-Stat }(5)=19.78[0 . \\
J-B=25.08[0.00]\end{array}$ & & \\
\hline
\end{tabular}

*(t-statistic in brackets) 
Fig. 1. Real Housing Price Index (HI)

$\mathrm{HI}$

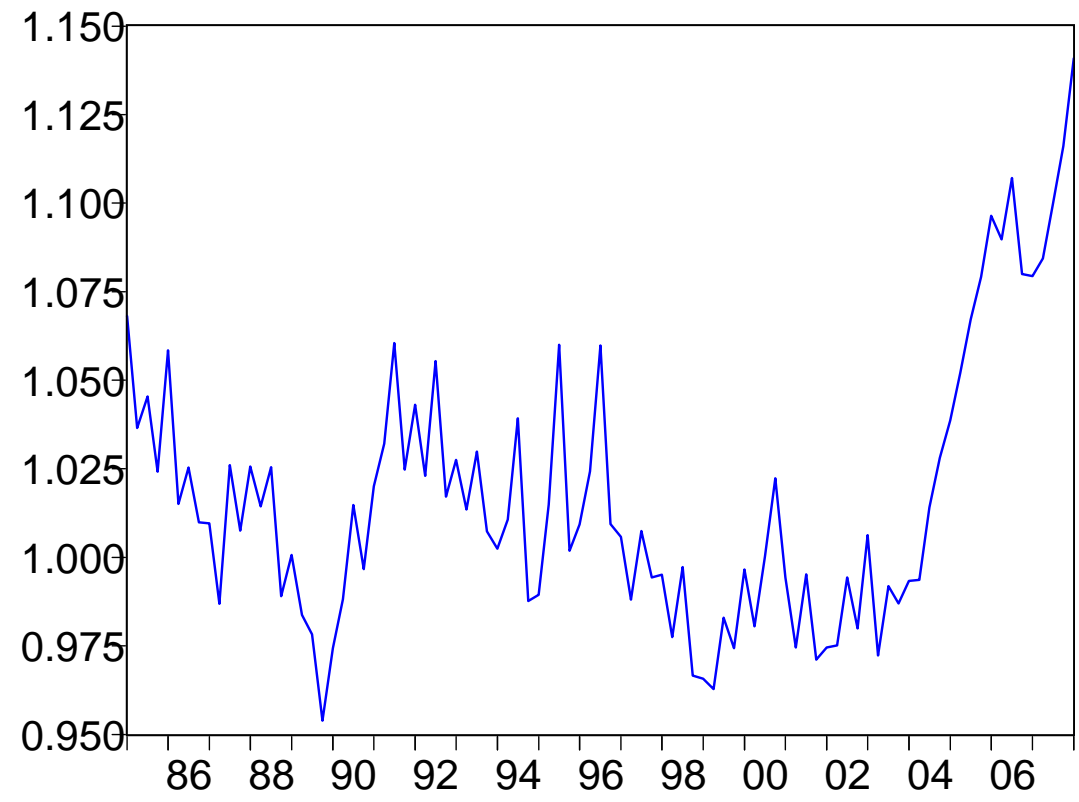

Fig. 2. Real Long Run Interest Rate (LR) and Unemployment Rate (UN)

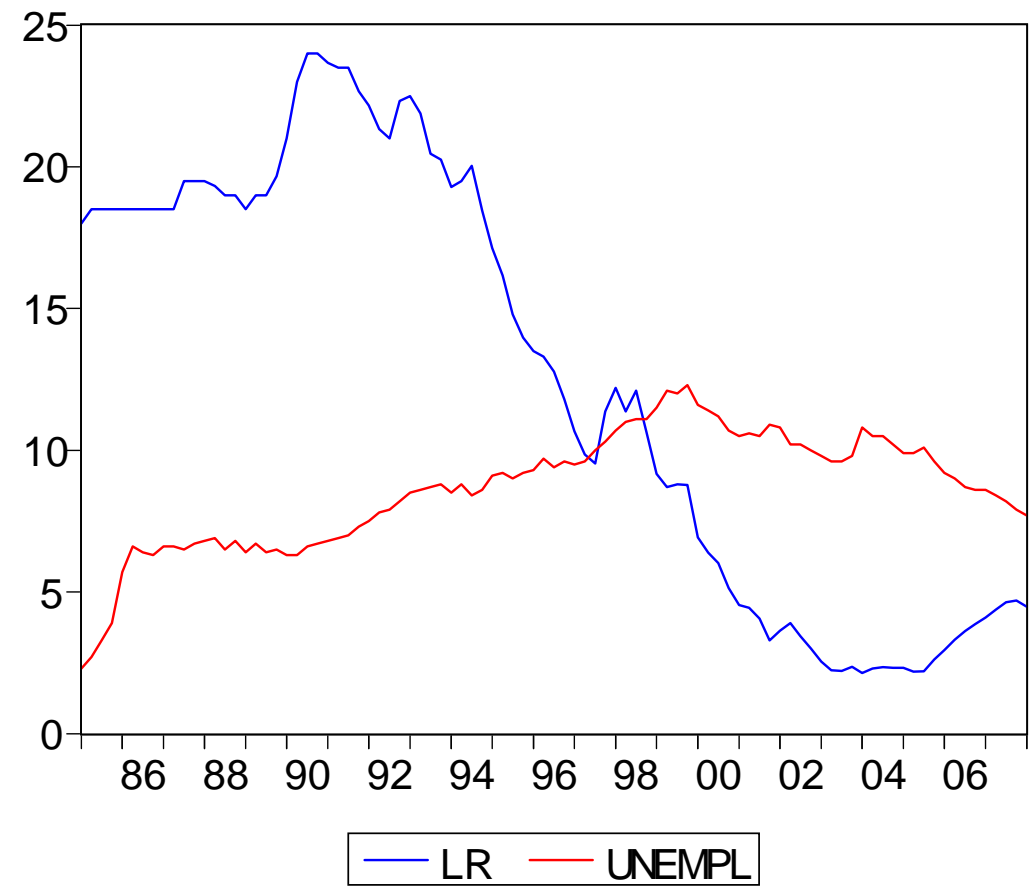


Fig. 3. Real Housing Price Index (HI) and Real Production Index (PROD)

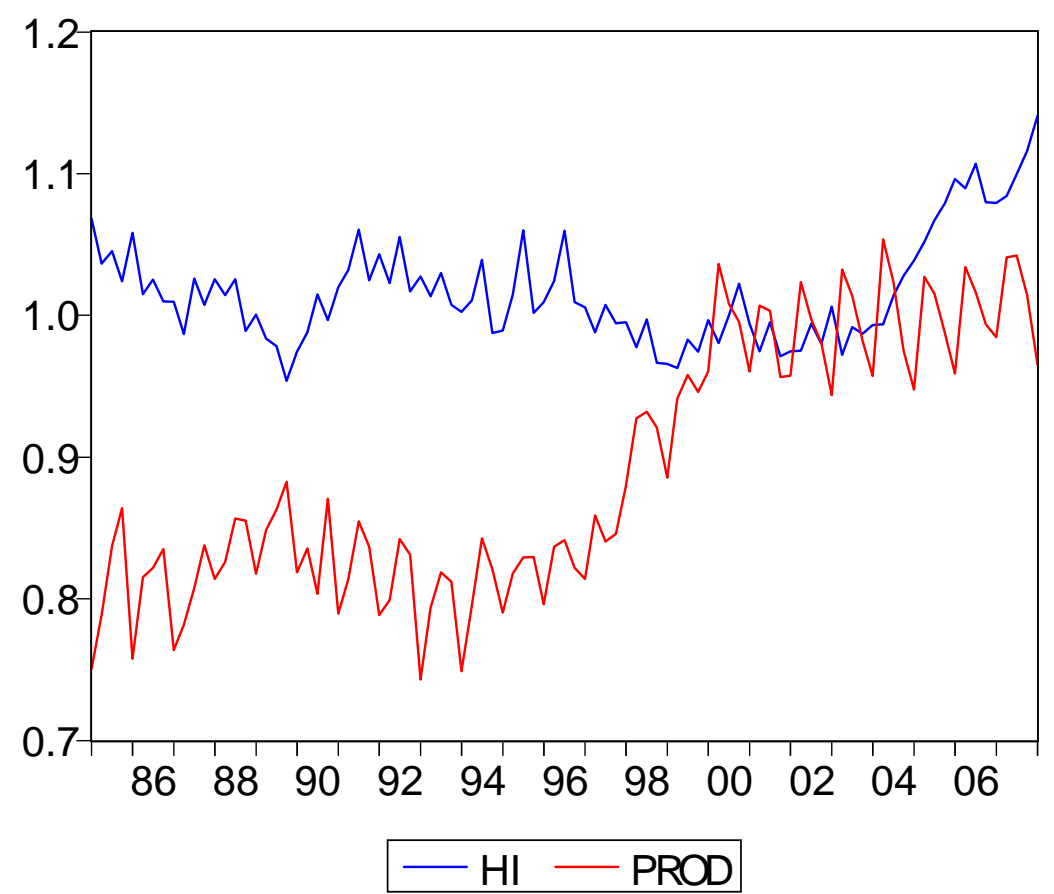

Fig. 4._Response of HI and ASE to Cholesky One S.D. Innovations

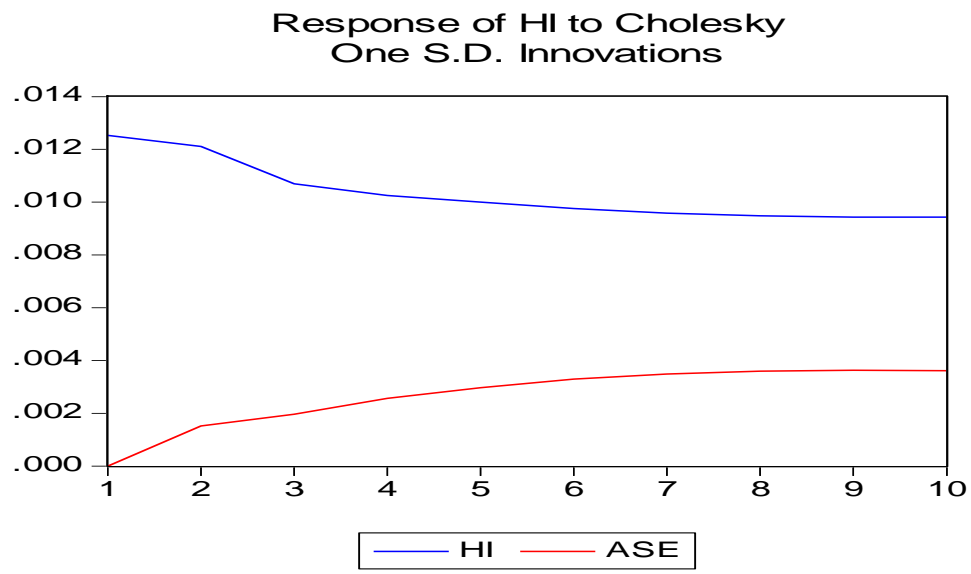

Response of ASE to Cholesky

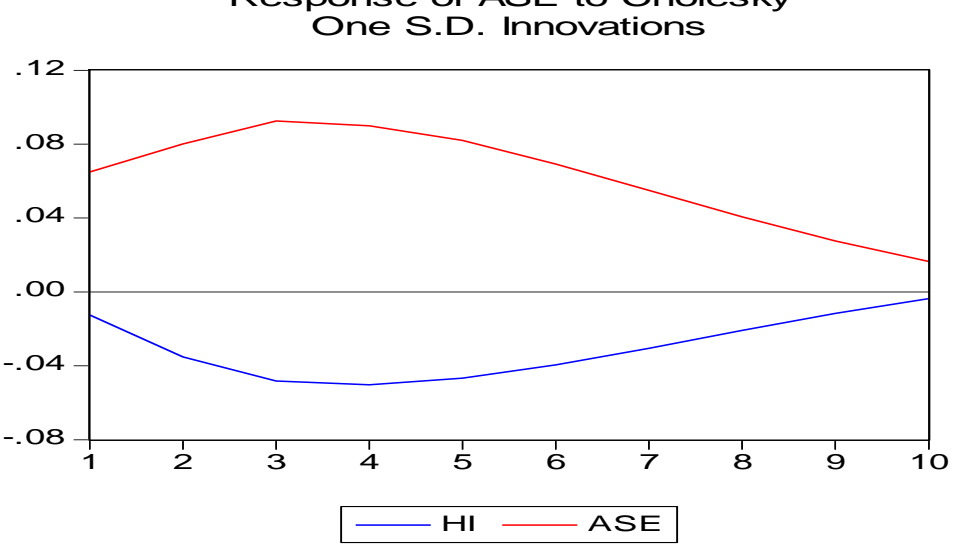

